\title{
Serous cystadenofibroma misdiagnosed as an ovarian malignancy
}

\author{
Dong Hyu Cho
}

Department of Obstetrics and Gynecology, Chonbuk National University Medical School, Jeonju, South Korea

\section{Correspondence to} Professor Dong Hyu Cho, obgyn2001@jbnu.ac.kr

Accepted 8 November 2018

\section{DESCRIPTION}

A 34-year-old woman was admitted to the hospital with lower abdominal discomfort for several months. Her menstrual cycle length was 28 days, and she experienced slight menstrual pain.

A soft, movable mass was palpated in the right adnexal region of the uterus on pelvic examination. Her routine full blood counts, serum biochemistry and tumour marker were within the normal ranges.

Pelvic ultrasound demonstrated complex cystic mass with solid components measuring $6 \times 3 \times 3 \mathrm{~cm}$ within the right adnexa. There was no free fluid in the pelvic cavity. Contrast-enhanced abdominal CT showed $6 \times 3 \times 3 \mathrm{~cm}$ sized lobulated solid cystic lesions with various sized nodules within the right adnexa (figure 1).

Under general anaesthesia, exploratory laparoscopy was performed on suspicion of an ovarian malignancy. The uterus and left adnexa appeared normal, but with a large oval to round yellow, grey and whitish coloured cystic to solid nodular bosselated tumours on the right ovary. The largest cyst measured $3 \times 3 \times 2 \mathrm{~cm}$ (figure 2 ). No enlargement of lymph node around the mass or metastasis was found. Intraoperative frozen section analysis suggested a benign cystadenofibroma.

The decision was made by the surgical team to perform right partial oophorectomy. There were no major intraoperative complications.

Pathological examination revealed serous cystadenofibroma composed of marked fibrotic stroma and cystic spaces lined by serous epithelium (figure 3).

The patient made an uneventful postoperative recovery and was discharged home on the third postoperative day.

Ovarian cystadenofibromas are relatively rare variants of epithelial tumours of ovary containing epithelial and fibrous stromal components. ${ }^{1}$ They
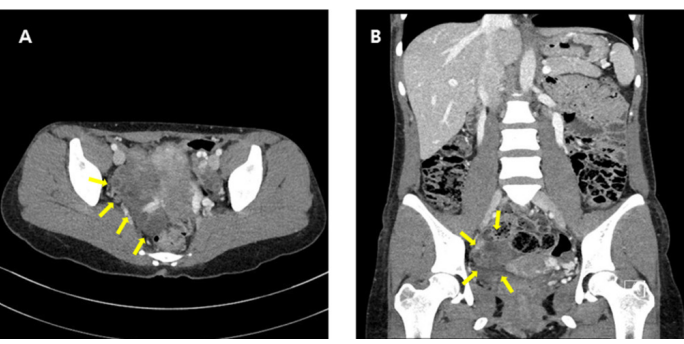

Figure 1 Contrast-enhanced abdominal CT shows lobulated solid cystic lesions with various sized nodules within the right adnexa.

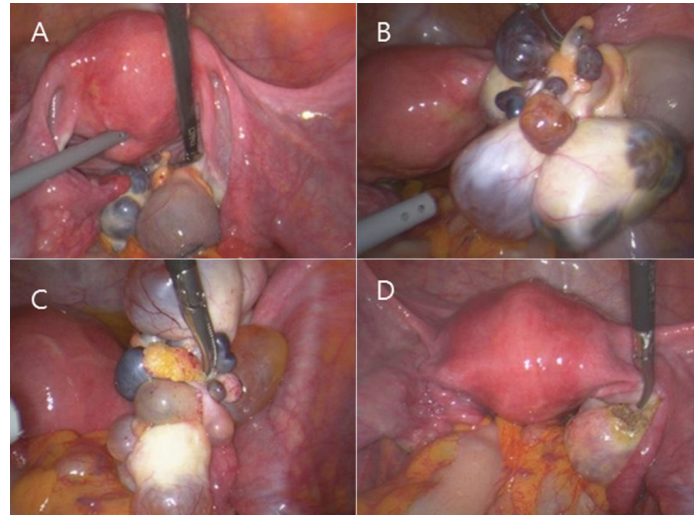

Figure 2 Intraoperative findings: (A-C) large oval to round yellow, grey and whitish coloured cystic to solid nodular bosselated tumours on the right ovary. (D) Partial oophorectomy was performed.
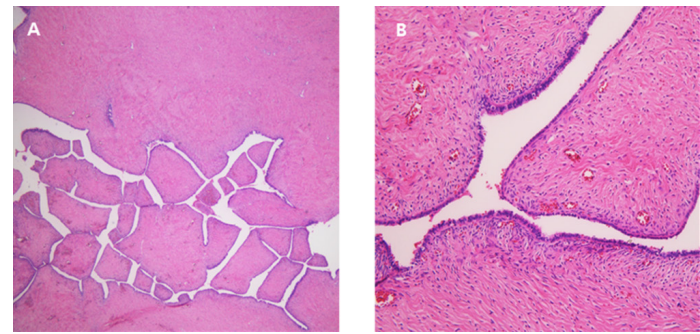

Figure 3 Histological features of serous cystadenofibroma. (A) Low power field shows marked fibrotic stroma (H\&E stain, $\times 40$ ). (B) The cystic spaces are lined by serous epithelium (H\&E stain, $\times 200)$.

account for $1.7 \%$ of all benign ovarian tumours and occur in women aged 15-65 years. Serous cystadenofibroma of ovary usually presents with symptoms such as abdominal pain, vaginal bleeding and increased girth.

Unlike CT or ultrasonography, characteristic MRI findings of dense fibrous stromal proliferation with scattered small cystic glandular structures on the T2-weighted images can help diagnose ovarian cystadenofibroma and differentiate between benign and malignant tumours. ${ }^{2}$

The treatment of choice is complete surgical removal of the tumour. The prognosis is generally excellent with prompt and appropriate treatment.

As these tumours can resemble the gross appearance of malignant tumours perioperatively, when available, frozen sections should be performed to direct the surgeon and prevent the patient from unnecessary extensive surgery. ${ }^{23}$ 


\section{Learning points}

- Ovarian cystadenofibromas are relatively rare variants of epithelial tumours of ovary containing epithelial and fibrous stromal components.

- The treatment of choice is complete surgical removal of the tumour.

- As these tumours can resemble the gross appearance of malignant tumours perioperatively, when available, frozen sections should be performed to direct the surgeon and prevent the patient from unnecessary extensive surgery.

Contributors I participated sufficiently in the work, including preparation of manuscript and agreed to accept equal responsibility for the accuracy of the contents of the paper. This manuscript has not planned to be submitted elsewhere.
Funding The authors have not declared a specific grant for this research from any funding agency in the public, commercial or not-for-profit sectors.

Competing interests None declared.

Patient consent Obtained.

Provenance and peer review Not commissioned; externally peer reviewed.

\section{REFERENCES}

1 Mechera R, Menter T, Oertli D, et al. Large ovarian cystadenofibroma causing large bowel obstruction in a patient with Klippel-Feil syndrome-a case report. Int J Surg Case Rep 2016;20:17-20.

2 Wasnik A, Elsayes K. Ovarian cystadenofibroma: a masquerader of malignancy. Indian J Radiol Imaging 2010;20:297-9.

3 Lee DH. A case of mucinous cystadenofibroma of the ovary. Case Rep Obstet Gynecol 2014;2014:1-4

Copyright 2018 BMJ Publishing Group. All rights reserved. For permission to reuse any of this content visit https://www.bmj.com/company/products-services/rights-and-licensing/permissions/

BMJ Case Report Fellows may re-use this article for personal use and teaching without any further permission.

Become a Fellow of BMJ Case Reports today and you can:

- Submit as many cases as you like

- Enjoy fast sympathetic peer review and rapid publication of accepted articles

- Access all the published articles

- Re-use any of the published material for personal use and teaching without further permission

For information on Institutional Fellowships contact consortiasales@bmjgroup.com

Visit casereports.bmj.com for more articles like this and to become a Fellow 